\title{
Seasonal changes in metabolic and temperature responses to cold air in humans
}

Citation for published version (APA):

van Ooijen, A. M. J., van Marken Lichtenbelt, W. D., van Steenhoven, A. A., \& Westerterp, K. R. (2004). Seasonal changes in metabolic and temperature responses to cold air in humans. Physiology \& Behavior, 82(2-3), 545-553. https://doi.org/10.1016/j.physbeh.2004.05.001

Document status and date:

Published: 01/01/2004

DOI:

10.1016/j.physbeh.2004.05.001

Document Version:

Publisher's PDF, also known as Version of record

Document license:

Taverne

Please check the document version of this publication:

- A submitted manuscript is the version of the article upon submission and before peer-review. There can be important differences between the submitted version and the official published version of record.

People interested in the research are advised to contact the author for the final version of the publication, or visit the DOI to the publisher's website.

- The final author version and the galley proof are versions of the publication after peer review.

- The final published version features the final layout of the paper including the volume, issue and page numbers.

Link to publication

\footnotetext{
General rights rights.

- You may freely distribute the URL identifying the publication in the public portal. please follow below link for the End User Agreement:

www.umlib.nl/taverne-license

Take down policy

If you believe that this document breaches copyright please contact us at:

repository@maastrichtuniversity.nl

providing details and we will investigate your claim.
}

Copyright and moral rights for the publications made accessible in the public portal are retained by the authors and/or other copyright owners and it is a condition of accessing publications that users recognise and abide by the legal requirements associated with these

- Users may download and print one copy of any publication from the public portal for the purpose of private study or research.

- You may not further distribute the material or use it for any profit-making activity or commercial gain

If the publication is distributed under the terms of Article $25 \mathrm{fa}$ of the Dutch Copyright Act, indicated by the "Taverne" license above, 


\title{
Seasonal changes in metabolic and temperature responses to cold air in humans
}

\author{
A.M.J. van Ooijen ${ }^{\mathrm{a}, \mathrm{b}, *}$, W.D. van Marken Lichtenbelt ${ }^{\mathrm{a}}$, A.A. van Steenhoven ${ }^{\mathrm{b}}$, K.R. Westerterp ${ }^{\mathrm{a}}$ \\ ${ }^{\mathrm{a}}$ Department of Human Biology, Maastricht University, P.O. Box 616, 6200 MD, Maastricht, The Netherlands \\ ${ }^{\mathrm{b}}$ Department of Energy Technology, University of Technology, P.O. Box 513, 5600 MB Eindhoven, The Netherlands \\ Received 15 January 2004; received in revised form 3 May 2004; accepted 10 May 2004
}

\begin{abstract}
The metabolic and temperature response to mild cold were investigated in summer and winter in a moderate oceanic climate.

Subjects were 10 women and 10 men, aged $19-36$ years and BMI $17-32 \mathrm{~kg} / \mathrm{m}^{2}$. Metabolic rate (MR) and body temperatures were measured continuously in a climate chamber with an ambient temperature of $22{ }^{\circ} \mathrm{C}$ for $1 \mathrm{~h}$ and subsequently $3 \mathrm{~h}$ of $15{ }^{\circ} \mathrm{C}$.

The average metabolic response during cold exposure, measured as the increase in $\mathrm{kJ} / \mathrm{min}$ over time, was significantly higher in winter $(11.5 \%)$ compared to summer $(7.0 \%, P<.05)$. The temperature response was comparable in both seasons. The metabolic response in winter was significantly related to the response in summer $\left(r^{2}=.47, P<.001\right)$. Total heat production during cold exposure was inversely related to the temperature response in both seasons (summer, $r^{2}=.39, P<.01$; winter $r^{2}=.32, P<.05$ ). In conclusion, the observed higher metabolic response in winter compared to summer indicates cold adaptation. The magnitude of the cold response varies, but the relative contribution of metabolic and temperature response was subject specific and consistent throughout the seasons, which can have implications for energy balance and body composition.
\end{abstract}

(C) 2004 Elsevier Inc. All rights reserved.

Keywords: Heat production; Body temperature; Energy expenditure; Cold; Adaptation

\section{Introduction}

In thermal physiology, there is a strong interest in human responses to extreme temperatures. Few studies are available about mild cold conditions and even fewer studies focussed on individual patterns of cold responses [1-3]. With respect to mild-cold exposure as met under daily living circumstances in many places on earth, metabolic and temperature effects cannot be deduced from the existing studies. Therefore, we studied physiological mildcold responses in a modern society in a moderate oceanic climate.

Upon entering a cold environment, heat balance is disturbed, and consequently, two main patterns of physiological adjustments may occur: insulative and metabolic, or a combination of these. The insulative adjustment in

* Corresponding author. Department of Human Biology, Maastricht University, Universiteitssingel 50, P.O. Box 616, 6200 MD, Maastricht, The Netherlands. Tel.: +31-43-3884596; fax: +31-43-3670976.

E-mail address: m.vanooijen@HB.unimaas.nl (A.M.J. van Ooijen). response to cold exposure is accomplished by peripheral vasoconstriction. This is called insulative vasomotor response. This restricts heat transfer from the internal organs to the skin, resulting in a decrease in skin temperature, which in turn results in a decrease in body heat loss [4].

The metabolic response results in an increase in metabolic rate $(\mathrm{MR})$, thus increasing heat production [4,5]. Several components of energy expenditure may contribute to the process: shivering thermogenesis (ST) [6,7], nonshivering thermogenesis (NST) [8-10], nonexercise activity thermogenesis (NEAT) [11], and activity-induced thermogenesis (AT). Under resting conditions, only the components ST, NST, and NEAT remain.

It is well known that the magnitude of the cold response, and to a lesser extent, the relative contribution of the metabolic and insulative vasomotor response, depends on the duration and severity of the cold exposure, the medium, water or air, and acclimatization $[12,13]$.

With respect to cold exposure, most studies are conducted using severe cold stress, with maximal temperatures $20{ }^{\circ} \mathrm{C}$ water or $5{ }^{\circ} \mathrm{C}$ air [8,14-16]. Only a few studies are available using mild-cold responses in air [17-20]. These 
studies, however, focus on energy metabolism, not on insulation. None of these studies are concerned with individual differences.

Physiological adjustments in response to chronic cold exposure are referred to as acclimatization, or acclimation under laboratory conditions. The acclimatization pattern appears to differ depending on the type of cold exposure, like the effect of the arctic climate [21], sleeping nude in the cold [22], or regular cold water immersions [23]. We wondered if the relatively small differences in environmental temperature as encountered in modern society, with central heated houses and good clothing, in a moderate oceanic climate would affect the physiological cold response.

In an acclimation study, using water immersion as cold stimulus, Bittel [4] showed interindividual differences in metabolic and insulative vasomotor response to extreme cold, and changes in response after acclimation. Recently, interindividual variation in mild-cold response was shown in subjects staying for 2 days in a respiration chamber at our laboratory [2]. Subjects that responded with increased metabolism in the cold, showed less insulative vasomotor response and vice versa. The average increase in energy metabolism amounted to $5 \%$ of 24-h energy expenditure. More interesting, the observed range in changes in metabolism compared to thermoneutral conditions was $0.15-1.45 \mathrm{MJ} /$ day, which can have significant metabolic consequences on the long term. A relatively large contribution of an insulative vasomotor response and failure of activation of thermogenesis is a risk for weight gain [24].

If seasonal changes in cold response exist, we wondered if the observed interindividual variation will be maintained throughout the seasons as well. In other words, is the type of cold response an individual trait? For example, it is known that relative body temperature is subject specific as shown by Rising et al. [25]. They found a significant individual variation in fasting oral temperature and in spite of changes of the temperature, interindividual differences in body temperature were maintained throughout semistarvation and refeeding [25].
This paper aims to investigate seasonal changes in response to mild cold. The study was conducted in a moderate oceanic climate with mild seasonal differences in environmental temperature and, in general, small differences between indoor and outdoor temperatures. To avoid the effect of activity and diet during cold exposure, resting conditions were studied.

It was hypothesized that individual differences in cold response exist ranging from a more insulative vasomotor response to a more metabolic response to cold, and that the metabolic response is inversely related to the insulative vasomotor response. Secondly, the individual pattern of cold response remains during acclimatization in winter compared to summer, while the magnitude of the response changes.

\section{Materials and methods}

\subsection{Subjects}

Ten women and 10 men, age ranging from 19 to 36 years and BMI ranging from 17 to $32 \mathrm{~kg} / \mathrm{m}^{2}$, participated in the study (Table 1). Subjects were not using any medication and were nonsmokers.

The volunteers were provided with detailed information concerning purpose and methods used in the study, before written consent was obtained. The Ethics Committee of Maastricht University approved the study. Most subjects were students spending average time on sports or daily living activities; none of them were extreme athletes or extremely active in outdoor activities. All but one of the women were either users of oral contraceptives or in preovulatory phase at the measurement day.

\subsection{Design}

Experiments took place at the end of the summer, in August and September, and all measurements were repeated with the same subjects at the end of the winter, in February and March, just after the warmest and coldest months of the

Table 1

Subject characteristics

\begin{tabular}{|c|c|c|c|c|c|c|}
\hline & \multicolumn{3}{|l|}{ Summer } & \multicolumn{3}{|l|}{ Winter } \\
\hline & Mean, $n=20$ & Males, $n=10$ & Females, $n=10$ & Mean, $n=20$ & Males, $n=10$ & Females, $n=10$ \\
\hline Age (years) & $26 \pm 5$ & $27 \pm 6$ & $25 \pm 3$ & & & \\
\hline Height (m) & $1.74 \pm 0.09$ & $1.82 \pm 0.04$ & $1.67 \pm 0.07^{\dagger}$ & & & \\
\hline Weight $(\mathrm{kg})$ & $71.1 \pm 14.4$ & $78.8 \pm 15.5$ & $63.3 \pm 8.1^{\dagger}$ & $72.0 \pm 14.8$ & $79.9 \pm 16.6$ & $64.2 \pm 6.9^{\dagger}$ \\
\hline FM (kg) & $16.1 \pm 7.1$ & $14.3 \pm 8.6$ & $17.9 \pm 5.1$ & $17.0 \pm 6.8 *$ & $15.7 \pm 8.9 *$ & $18.4 \pm 4.0$ \\
\hline FFM (kg) & $55.0 \pm 12.0$ & $65.5 \pm 8.9$ & $45.4 \pm 4.8^{\dagger}$ & $55.0 \pm 11.9$ & $64.2 \pm 9.8$ & $45.8 \pm 4.2^{\dagger}$ \\
\hline $\operatorname{SMR}(\mathrm{kJ} / \mathrm{min})$ & $4.58 \pm 0.70$ & $5.10 \pm 0.46$ & $4.07 \pm 0.48^{\dagger}$ & $4.58 \pm 0.70$ & $5.08 \pm 0.58$ & $4.08 \pm 0.37^{\dagger}$ \\
\hline $\mathrm{RMR}(\mathrm{kJ} / \mathrm{min})$ & $4.74 \pm 0.72$ & $5.25 \pm 0.56$ & $4.23 \pm 0.46^{\dagger}$ & $4.75 \pm 0.73$ & $5.24 \pm 0.58$ & $4.26 \pm 0.51^{\dagger}$ \\
\hline
\end{tabular}

Values are means \pm S.D. FM, fat mass; FFM, fat-free mass; SMR, sleeping metabolic rate; RMR, resting metabolic rate.

* $P<.05$ between summer and winter.

${ }^{\dagger} P<.05$ between males and females. 
year (Fig. 1). Subjects visited the laboratory for an overnight stay and the following morning to carry out the experiment. To avoid an effect of diet-induced thermogenesis, subjects fasted starting $10 \mathrm{~h}$ prior to the cold test until the end of the test. From 10:00 p.m. until 8:00 a.m., the ambient temperature was $22{ }^{\circ} \mathrm{C}$. Sleeping metabolic rate (SMR) and intestinal temperature were measured. Subjects were lying on a bed and covered with a duvet $\left(375 \mathrm{~g} / \mathrm{m}^{2}\right)$.

In the morning, subjects moved to a stretcher where they were lying in semisupine position. MR and intestinal, rectal, and skin temperatures were measured for $1 \mathrm{~h}$ at an ambient temperature of $22{ }^{\circ} \mathrm{C}$ followed by $3 \mathrm{~h}$ during which the subjects were exposed to the cold. The subjects stayed in the same room, which was cooled from 22 to $15{ }^{\circ} \mathrm{C}$ in $45 \mathrm{~min}$. They were wearing standard clothing with an insulative value of 0.71 clo $\left(\mathrm{Icl}=0.109 \mathrm{~m}^{2} \cdot{ }^{\circ} \mathrm{C} / \mathrm{W}\right)$, consisting of sweatpants $(0.28$ clo), a sweater ( 0.37 clo), socks that cover only the feet $(0.02$ clo), and panties and a bra for women and briefs for men (0.04 clo). The face, hands, and ankles were exposed directly to the environment.

Data was averaged over the last $45 \mathrm{~min}$ of the hour at $22{ }^{\circ} \mathrm{C}\left(t_{0}\right)$ and over every hour at $15{ }^{\circ} \mathrm{C}\left(t_{1}, t_{2}\right.$, and $\left.t_{3}\right)$.

Subjects were not allowed to exercise the day before the measurement and were fasting from the moment they entered the chamber until the experiment was finished.

Body composition and maximal oxygen uptake $\left(\mathrm{VO}_{2 \max }\right)$ were determined on a separate visit within 1 week of the experiment.

\subsection{Measurements}

Body composition was calculated using the threecompartment model according to Siri [26] with the following equation.

$$
\begin{aligned}
\mathrm{FM}(\%)= & (2.118 / \mathrm{Db}(\mathrm{kg} / \mathrm{l}))-(0.78 \times \mathrm{TBW}(\mathrm{l}) \\
& / \mathrm{BM}(\mathrm{kg}))-1.354) \times 100
\end{aligned}
$$

where $\mathrm{Db}$ is the density of the body, TBW is the total amount of body water, and BM is body mass.

For this calculation, body density and total body water were determined using underwater weighing and deuterium dilution, respectively [27]. The latter was determined according to the Maastricht protocol [28]. In the evening after collecting a baseline urine sample, a single dose of deuterium dilution was ingested. Deuterium enrichment was measured in urine from the second voiding of the following morning.

During the night, $\mathrm{O}_{2}$ consumption and $\mathrm{CO}_{2}$ production were measured in a $14 \mathrm{~m}^{3}$ respiration chamber as previously described [29]. SMR was defined as the average MR during at least $3 \mathrm{~h}$ of sleep with the lowest activity as registered by radar. In most cases, this was between 3:00 and 6:00 a.m. During the morning tests, $\mathrm{O}_{2}$ consumption and $\mathrm{CO}_{2}$

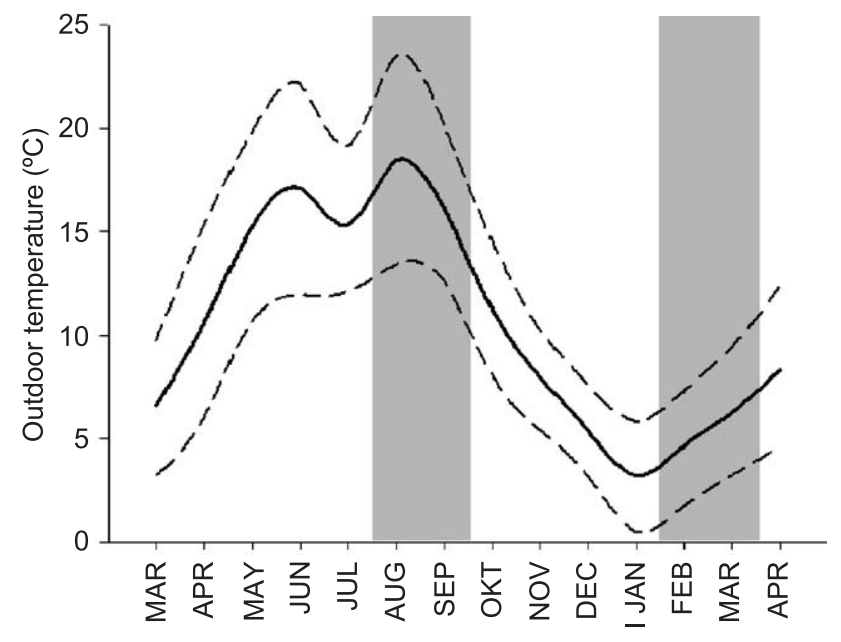

Fig. 1. Monthly mean of daily average temperatures from March 2000 until April 2001 with monthly mean values of daily maximum and minimum temperatures $\left({ }^{\circ} \mathrm{C}\right)$ at station Maastricht, The Netherlands. Measured by the Royal Dutch Meteorological Institute. - Monthly mean of daily average temperatures. - - , Monthly mean of daily maximum temperatures. - - - Monthly mean of daily minimum temperatures. $\square$, Test period

production were measured with an automated respiratory gas analyser using a ventilated hood system (Omnical, IDEE, Maastricht, The Netherlands) using the same methods of analysis as the respiration chamber. Gas analyses were performed by dual paramagnetic $\mathrm{O}_{2}$ analysers and dual infrared $\mathrm{CO}_{2}$ analysers (type 1156, 1507, 1520; Servomex, Crowborough, Sussex, UK), similar to the analysis system described by Schoffelen et al [29]. MR was calculated from these data according to Weir [30] republished as classical article (1990) using the following equation.

$\operatorname{MR}(\mathrm{kJ} / \mathrm{min})=16.3 \times$ oxygen consumed $(1 / \mathrm{min})$

$$
+4.6 \text { carbon dioxide produced }(1 / \mathrm{min})
$$

Resting metabolic rate (RMR) was defined as the MR $(\mathrm{kJ} / \mathrm{min})$ in a thermoneutral environment, lying still and awake in a postabsorptive state.

$\mathrm{VO}_{2 \max }$ was determined during an incremental exercise test, performed on a cycle ergometer (Lode, Excalibur, Groningen, The Netherlands). Men and women started to cycle at 100 and $75 \mathrm{~W}$, respectively. This workload was used as a warming up period for $5 \mathrm{~min}$, followed by a workload increase of $50 \mathrm{~W}$ every $2.5 \mathrm{~min}$ until heart rate reached $160 \mathrm{bpm}$, then the workload was increased $25 \mathrm{~W}$ every $2.5 \mathrm{~min}$ until exhaustion. The highest oxygen uptake averaged over $30 \mathrm{~s}$ was used as $\mathrm{VO}_{2 \max }$. Criteria for maximal performance were a forced ventilation, a levelling off of oxygen uptake, or a respiratory quotient above 1.1 .

Core temperature was measured by two means, rectally and in the intestine. The variation in intestinal temperature can be quite large. The disadvantage of rectal temperature, 
however, is that it can be delayed compared to core temperature, especially during cold exposure tests, and when core compartment size is reduced, rectal temperature can deviate from the core [31]. Therefore, we measured intestinal temperature as well.

Rectal temperature was measured continuously by a thermistor-probe (YSI probes, series 402, Yellow Springs Instruments, Ohio, USA) inserted for $10 \mathrm{~cm}$. Intestinal temperature was measured by an ingestible telemetry pill (CorTemp, Human Technologies, St. Petersburg, FL, USA), which was ingested before entering the respiration chamber [32], which was the evening before the measurements in the morning.

Skin temperatures were measured by surface thermistors (YSI probes, series 409B, Yellow Springs Instruments) placed on the back of the hand, upper arm, chest located at the $\mathrm{m}$. pectoralis, abdomen located just below the right ribs, on the back located just below the right ribs, thigh, calf, and foot. Temperatures were measured continuously for $50 \mathrm{~s}$ out of every minute and saved every minute.

Shivering was detected using electromyography (EMG; Tiretherm, IDEE). EMG signals were amplified 100 times. These signals were filtered between 33 and $160 \mathrm{~Hz}$ and at the same time amplified for the second time between 2 and 11 times (adjustable). The signal proceeded through a signal comparator at a fixed reference level $(1 \mathrm{~V})$. The signal output then consisted of high-frequency pulses, which were counted and recorded for $50 \mathrm{~s}$ out of every $60 \mathrm{~s}$. The second amplification factor was adjustable by the experimenter and was set before the start of the experiment, when the subject was already in the experimental setup. The factor was chosen between 2 and 11 times, as sensitive as possible just above noise level. EMG electrodes were placed $3 \mathrm{~cm}$ apart on the skin at the $\mathrm{m}$. pectoralis major [6,33]. This site was chosen because in people having a normal amount of fat, shivering starts in the upper trunk region, and propagates towards the extremities [33]. In addition, every $15 \mathrm{~min}$, subjects were asked if they felt if they were shivering and the observer checked the subjects to see if they were shivering. Examples of EMG measurements with and without shivering are presented in Fig. 2.

\subsection{Calculations}

Mean skin temperature was calculated according to Ramanathan [34], using the following equation.

Mean skin temperature $\left({ }^{\circ} \mathrm{C}\right)$

$$
\begin{aligned}
= & 0.3\left(T \text { chest }\left({ }^{\circ} \mathrm{C}\right)+T \operatorname{arm}\left({ }^{\circ} \mathrm{C}\right)\right) \\
& +0.2\left(T \text { thigh }\left({ }^{\circ} \mathrm{C}\right)+T \operatorname{leg}\left({ }^{\circ} \mathrm{C}\right)\right)
\end{aligned}
$$

The distal temperature, calculated averaging hand and foot temperatures, represents the skin most distant from the core and is expected to show the strongest insulative
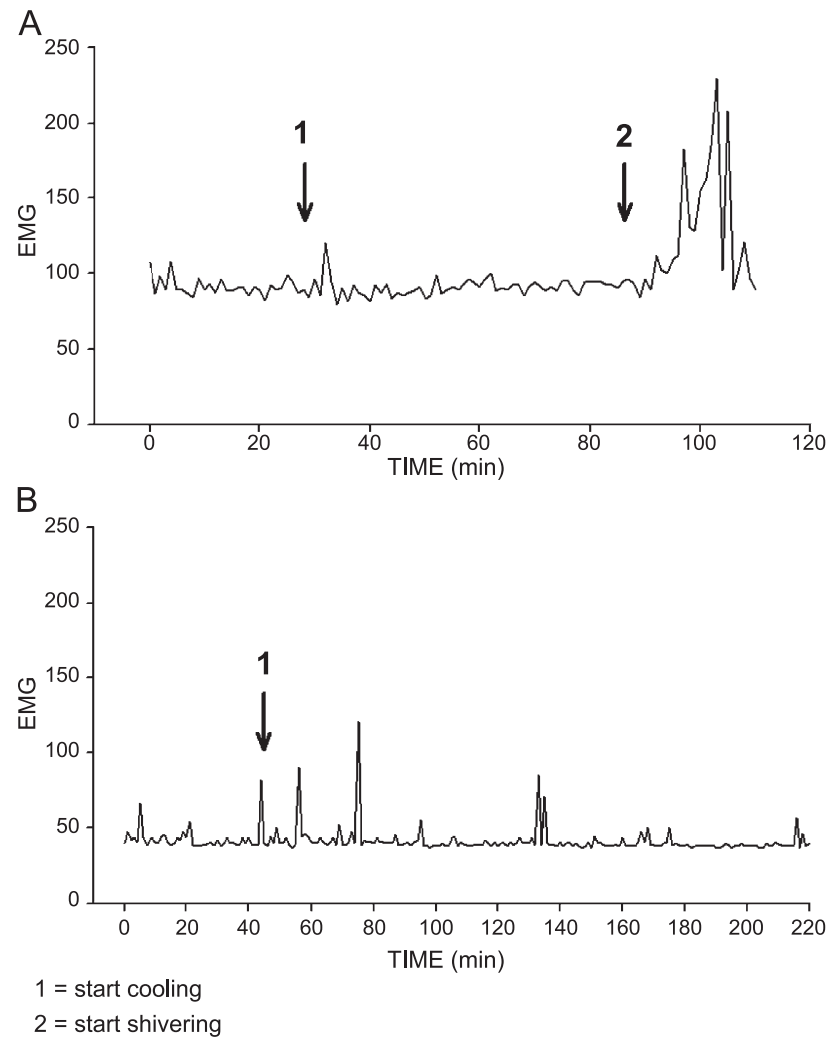

Fig. 2. Example of EMG measurement. (A) An EMG measurement of a test where shivering was induced. (B) A typical example of an EMG measurement of the present study. $1=$ Start of cooling, $2=$ start shivering.

vasomotor response. Temperature gradients, as a measure of insulation, were calculated between intestine and mean skin temperature ( $T$ intestine-skin), intestine and distal skin temperature (Tintest-dist), rectal and mean skin (Trectalskin), and between rectal and distal skin temperature (Trect-dist) [23].

The incremental area under the curve (AUCinc) was calculated by subtracting RMR (MR at $22{ }^{\circ} \mathrm{C}$ ) from the total area under the curve (AUCtot), and represents the total cold-induced thermogenesis. The area under the curve was calculated using data over 1-min intervals. The change in MR during cold exposure (during $t_{0}-t_{3}$ ) was calculated as well $(\mathrm{kJ} / \mathrm{min})$ as a measure of cold-induced thermogenesis.

\subsection{Statistical analyses}

Data are reported as means \pm S.D. For statistical analyses, all data was averaged over the last $45 \mathrm{~min}$ of the hour at $22{ }^{\circ} \mathrm{C}$ ambient temperature $\left(t_{0}\right)$ and over every subsequent hour at $15{ }^{\circ} \mathrm{C}\left(t_{1}, t_{2}\right.$, and $\left.t_{3}\right)$. For intraindividual differences (i.e., between the two ambient temperatures) in MR and body temperatures and for interindividual differences, paired and unpaired $t$ tests were used, respectively. ANOVA for repeated measurements was used to test the metabolic response to mild cold. For MR calculation, the AUCinc and AUCtot were calculated over $t_{0}-t_{3}$, in summer and winter. 
Differences in cold response between seasons were tested by paired $t$ tests. Regression analysis was used to study the relation between metabolic and insulative vasomotor response, stratified by season. Results were considered statistically significant when $P<.05$.

\section{Results}

\subsection{Body composition}

Physical characteristics of the subjects are given in Table 1 . Men were significantly taller, heavier, and had a higher fat-free mass (FFM; $\mathrm{kg}$ ) than women (Table 1, $P<.05)$. Fat mass ranged between $8.2 \%$ and $30.9 \%$ in men and between $20.7 \%$ and $36.0 \%$ in women.

Mean FFM $(\mathrm{kg})$ remained unchanged and fat mass (FM; $\mathrm{kg}$ ) was increased significantly in winter in males (Table 1). As a result, in men in winter, fat percentage was significantly higher and the percentage FFM was lower than in summer $(1.5 \%, P<.05)$. The same trend occurred in the females.
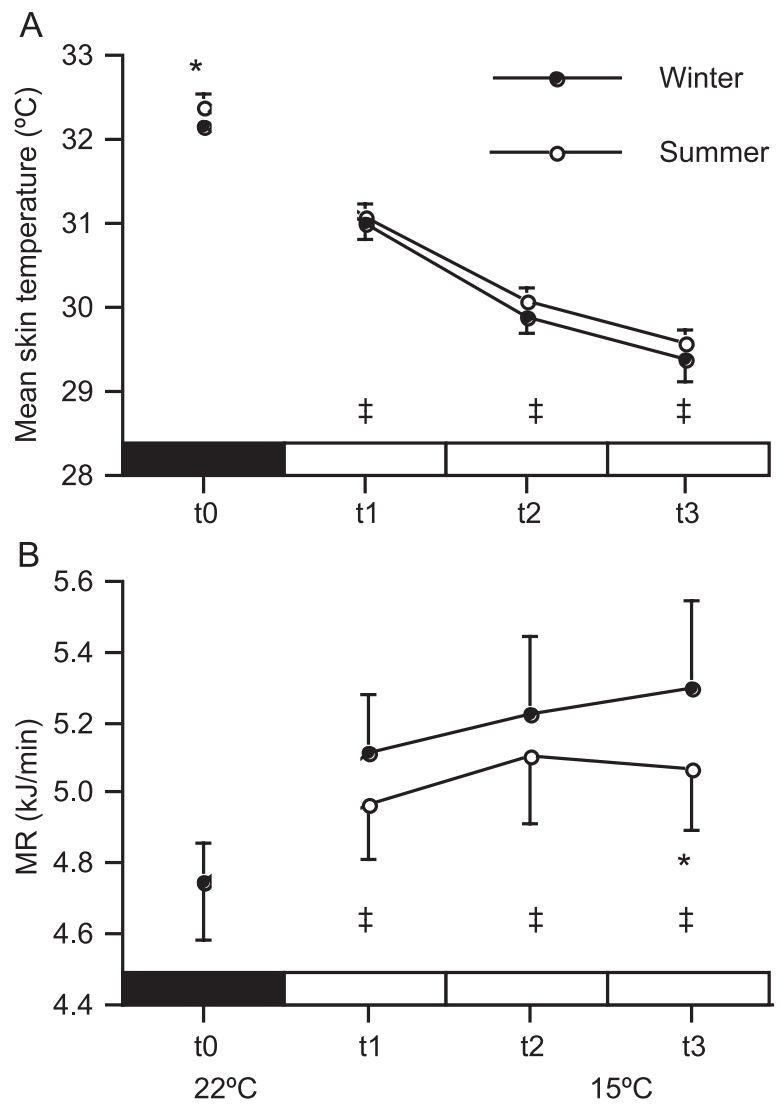

Fig. 3. (A) Mean skin temperature $\left({ }^{\circ} \mathrm{C}\right) \pm$ S.E.M. during neutral (closed symbols $22{ }^{\circ} \mathrm{C}$ ) and mild cold (open symbols $15{ }^{\circ} \mathrm{C}$ ) condition, in summer and winter. (B) MR \pm S.E.M. during neutral (closed symbols 22 ${ }^{\circ} \mathrm{C}$ ) and mild-cold (open symbols $15{ }^{\circ} \mathrm{C}$ ) condition, in summer and winter. ${ }^{*} P<.05$ summer versus winter. ${ }^{\ddagger} P<.05$ versus $22{ }^{\circ} \mathrm{C}$ in both summer and winter.

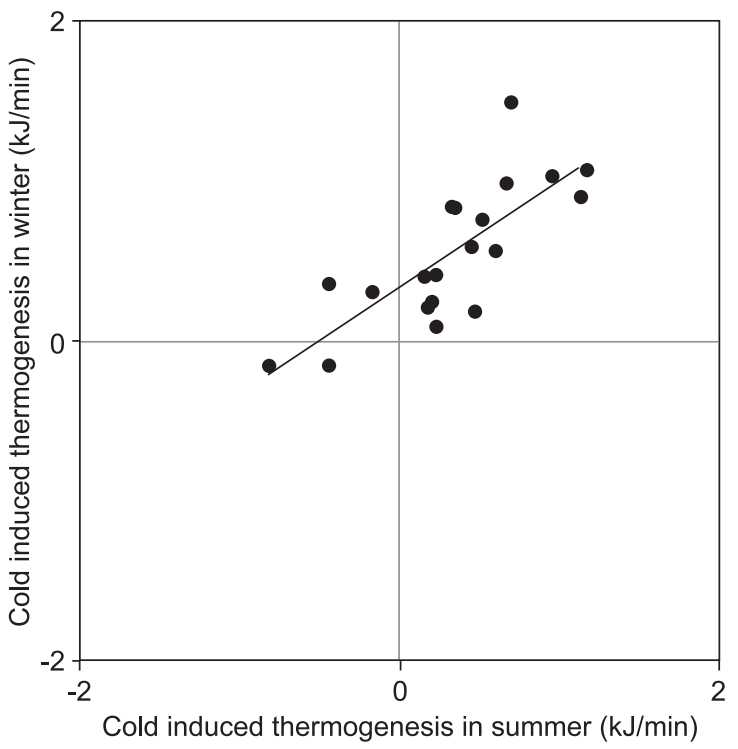

Fig. 4. Cold-induced thermogenesis (change in MR during cold exposure in $\left.\mathrm{kJ} / \mathrm{min} ; y=0.66 x+0.33, r^{2}=.61, P<.001\right)$.

\subsection{Metabolism}

Average MR (SMR and RMR) was higher in males compared to females (Table 1). Interindividual variation in SMR and RMR at $22{ }^{\circ} \mathrm{C}$ was mainly explained by variation in FFM in both summer and winter (SMR $r^{2}=.81$, RMR $r^{2}=.84$ in summer and SMR $r^{2}=.89$, RMR $r^{2}=.81$ in winter; all $P$ values $<.0001)$. Including $\mathrm{FM}$ in multiple linear regression analysis did not result in a significant increase of explained variation. After adjustment for body composition in multiple linear regression analysis, no significant gender differences in SMR and RMR were found. There were no significant differences between seasons in SMR, RMR (Table 1), or $\mathrm{VO}_{2 \max }$.

During $t_{1}-t_{3}$, no shivering was registered by EMG and the subjects did not report any sensation of shivering. In both seasons, MR was significantly increased during cold exposure $\left(t_{1}-t_{3}\right)$, compared to $t_{0}$ (Fig. 3B, ANOVA for repeated measurements, $P<.001)$. In summer, the average MR increased from $4.7 \pm 0.7 \mathrm{~kJ} / \min \left(t_{0}\right)$ to $5.1 \pm 0.8 \mathrm{~kJ} / \mathrm{min}$ $\left(t_{3}\right)$ and in winter, MR increased from $4.7 \pm 0.7 \mathrm{~kJ} / \mathrm{min}\left(t_{0}\right)$ to $5.3 \pm 0.9 \mathrm{~kJ} / \mathrm{min}\left(t_{3}\right)$. On average, the increase was $7.0 \pm 10.5 \%(P<.05)$ in summer and $11.5 \pm 9.1 \%$ $(P<.01)$ in winter, respectively $\left(t\right.$ test: values at $t_{3}$ versus $\left.t_{0}\right)$. The amount of cold-induced thermogenesis, calculated as the AUCinc was slightly but not significantly higher in winter compared to summer. At $t_{3}$, however, the increase in MR $(\mathrm{kJ} / \mathrm{min})$ was significantly larger in winter than in summer (Fig. $3, P<.01$ ). A large interindividual variation in the increase in heat production was found, which was consistent throughout the seasons. The metabolic response ranged from a decrease of $4 \%$ to an increase of $30 \%$ in winter and from a decrease of $12 \%$ to an increase of $24 \%$ in summer. Cold-induced thermogenesis $(\mathrm{kJ} / \mathrm{min})$ in summer 
Table 2

Body temperatures and temperature gradients $\left({ }^{\circ} \mathrm{C}\right)$ during neutral $\left(22^{\circ} \mathrm{C}\right)$ and mild-cold $\left(15^{\circ} \mathrm{C}\right)$ environmental conditions in summer and in winter

\begin{tabular}{|c|c|c|c|c|c|}
\hline & & \multicolumn{2}{|l|}{ Summer } & \multicolumn{2}{|l|}{ Winter } \\
\hline & & $22{ }^{\circ} \mathrm{C}$ & $15^{\circ} \mathrm{C}$ & $22{ }^{\circ} \mathrm{C}$ & $15^{\circ} \mathrm{C}$ \\
\hline \multirow[t]{2}{*}{$T$ core } & $T$ intestine & $36.8 \pm 0.4$ & $36.9 \pm 0.4$ & $36.9 \pm 0.3$ & $37.0 \pm 0.4^{\ddagger}$ \\
\hline & $T$ rectum & $36.8 \pm 0.3$ & $36.8 \pm 0.4$ & $36.9 \pm 0.3$ & $37.0 \pm 0.6$ \\
\hline$T$ periphery & $T$ skinR & $32.4 \pm 0.6 *$ & $29.6 \pm 0.8^{\ddagger}$ & $32.1 \pm 0.5$ & $29.4 \pm 1.1^{\ddagger}$ \\
\hline \multirow[t]{4}{*}{$T$ gradients } & $T$ intestine-skin & $4.5 \pm 0.7$ & $7.4 \pm 0.8^{\ddagger}$ & $4.7 \pm 0.6$ & $7.6 \pm 1.2^{\ddagger}$ \\
\hline & $T$ rectal-skin & $4.3 \pm 0.5 *$ & $7.1 \pm 0.9^{\ddagger}$ & $4.8 \pm 0.5$ & $7.4 \pm 1.1^{\ddagger}$ \\
\hline & $T$ intestine - dist & $6.2 \pm 1.5$ & $13.3 \pm 2.3^{\ddagger}$ & $6.1 \pm 1.1$ & $14.4 \pm 2.5^{\ddagger}$ \\
\hline & $T$ rectal-dist & $6.2 \pm 1.5$ & $14.9 \pm 2.1^{\ddagger}$ & $6.2 \pm 1.2$ & $14.2 \pm 2.5^{\ddagger}$ \\
\hline
\end{tabular}

Values are means \pm S.D. in degrees centigrade. TskinR, mean skin temperature calculated according to Ramanathan [34].

* $P<.05$ between summer and winter.

$\ddagger P<.01$ between a neutral ambient temperature and mild cold.

was significantly related to cold-induced thermogenesis in winter (Fig. $4, r^{2}=.61, P<.001$ ). In summer and winter, approximately two thirds $(70 \%$ and $65 \%)$ of the metabolic response of $t_{3}$ was reached at $t_{1}$. If only the period was considered when subjects were exposed to the cold (i.e., $t_{1}-$ $t_{3}$ ), a significant increase from $t_{1}$ to $t_{3}$ was found, in winter, but not in summer (ANOVA repeated measures; winter $P<.01$, summer $P=.13$ ).

\subsection{Body temperatures}

Table 2 summarizes the body temperatures measured during the experiment.

No significant difference was found between rectal and intestinal temperature in summer and winter and during thermoneutral and mild-cold conditions. A small increase in rectal and intestinal temperature was found in response to the mild cold. All skin temperatures decreased significantly during exposure to mild cold $(P<.01)$ in winter as well as in summer (Table 2, Fig. 3A). The temperature gradient between rectal and mean skin temperature (Trectal-skin) at $t_{0}$ was significantly higher in winter than in summer (Table 2).

\subsection{Metabolism versus insulative parameters}

The average MR ( $\mathrm{kJ} / \mathrm{min})$ was in both summer and winter negatively related to the increase in Tintestine-dist (Fig. 5, summer, $r^{2}=.38, P<.01$; winter $r^{2}=.31, P<.05$ ). In summer and winter, the change in intestinal temperature from $t_{0}$ to $t_{3}$ was positively related to $\mathrm{FM}(\% ; P<.05)$. At $t_{3}$ in winter, the temperature gradient between intestine and skin was positively related to $\mathrm{FM}(\% ; P<.05)$.

\section{Discussion}

Three hours of cold exposure revealed an increase in MR of $7.0 \%$ in summer and $11.5 \%$ in winter. The increase in winter was significantly higher than in summer. In winter, metabolism was still increasing at the end of the experiment, while in summer, it seemed to be stabilized. This could mean that in winter, MR during the time of exposure did not reach a steady state situation, while in summer, an equilibrium was reached.

Individual MRs were related to FFM. The increase in MR, however, was not related to either FFM or FM. Neither could the seasonal difference in metabolic response be attributed to changes in body composition or physical fitness. This indicates that anthropometry is not the explanation and the reason for the differences could be in autonomic or endocrinological functions. On the long term, however, body composition can be affected by differences in metabolic response.

Interestingly, the average drop in mean skin temperatures during cold exposure did not differ between the seasons. Nevertheless, the combination of an equal insulative vasomotor response with a higher cold-induced thermogenesis seems to point towards a smaller heat debt in winter. Earlier studies under more severe conditions show that cold acclimation is characterized by a decrease in heat debt in response to cold [4]. Therefore, we conclude that even in a moderate climate, cold acclimation occurred.

The study clearly shows interindividual variation in cold response. The change in intestine-distal temperature gradient implies a change in insulation, which was inversely related to the average MR during cold exposure (Fig. 5). This means that some people tend to respond in a more metabolic way and others in a more insulative way. This was comparable to a study under mild-cold conditions using 2 days of mild cold [2].

Interestingly, this study shows that those subjects showing a high metabolic response in summer do so again in winter (Fig. 4). This suggests that the type of response indeed is subject specific. The variation in metabolic response is large; in winter, the range was from -0.16 to $+1.49 \mathrm{~kJ} / \mathrm{min}$. The negative metabolic response could be a $\mathrm{Q}_{10}$ effect due to the cooling of peripheral tissue. The possibility, however, that the response of $-0.16 \mathrm{~kJ} / \mathrm{min}$ lies within the accuracy of the measurement should not be neglected. This variation in response between subjects has been found earlier in 24-h energy expenditure [2]. The present study shows that this variation in 24-h energy expenditure can at least in part be explained by the change in RMR. The magnitude of the 

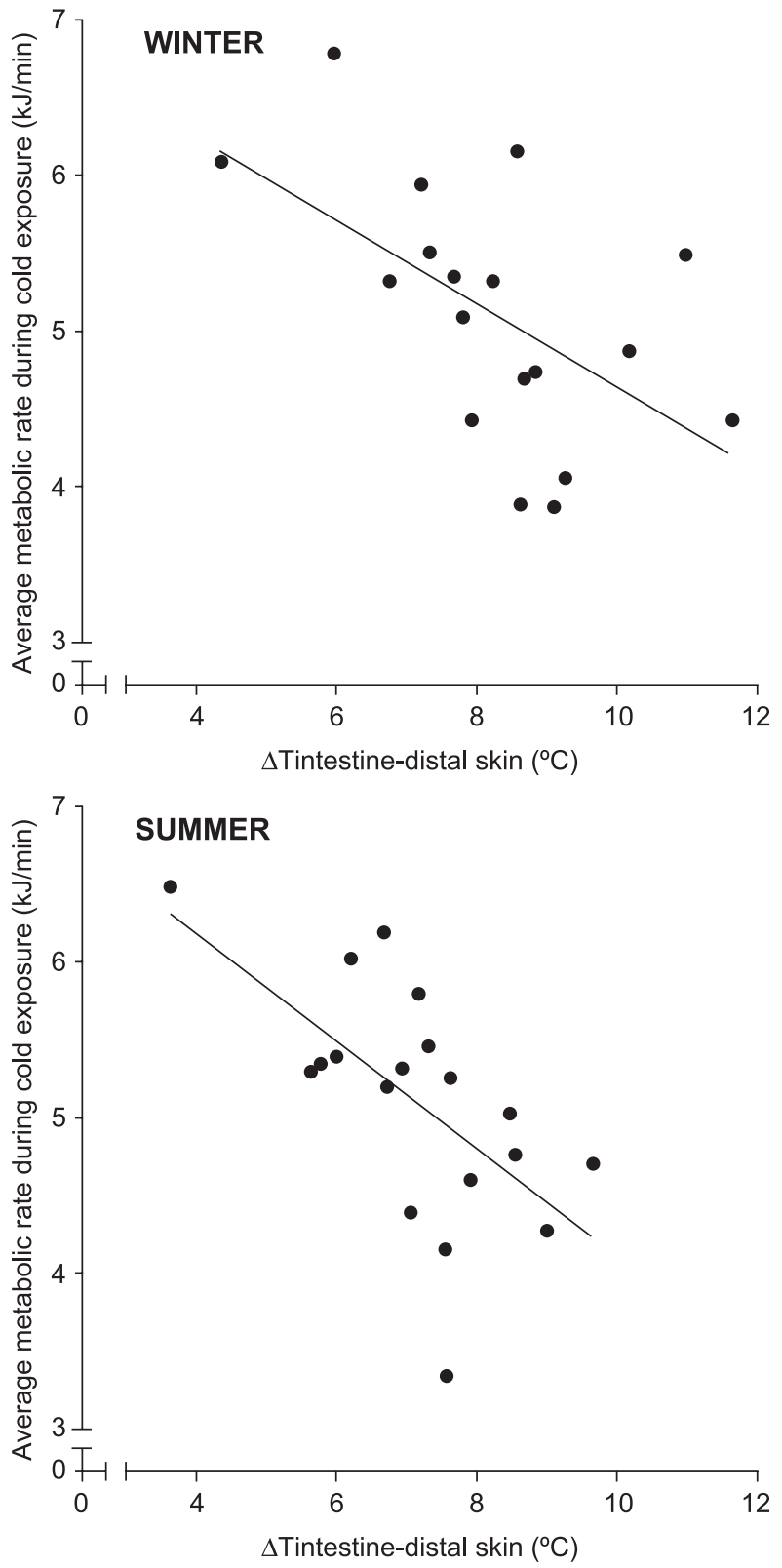

Fig. 5. Average MR during cold exposure $(\mathrm{kJ} / \mathrm{min})$ versus change in intestinal-distal temperature gradient $\left({ }^{\circ} \mathrm{C}\right)$ in summer and winter. Winter: $y=-0.27 x+7.32, r^{2}=.31, P<.05$. Summer: $y=-0.34 x+7.56$, $r^{2}=.38, P<.01$.

metabolic response can have important health implications. Some people tend to be more energy efficient than others under the test circumstances. These (mild) circumstances are common in daily life. Therefore, it is possible that some people deal with the small temperature fluctuations encountered in real life in a much more efficient way than others. Those that are efficient are more prone to develop obesity [24]. This lines up with an earlier study showing reduced cold-induced metabolic response in obese as compared to lean subjects [35].

O'Brien et al. [15] suggested that core cooling during the adaptation period is necessary to induce an enhancement in sympathetic activation during cold exposure. In their study, exercise was applied to prevent core cooling during the experimental cold adaptation period which resulted in lower norepinephrine levels [15]. Although the exact amount and duration of cold exposure in daily life in wintertime in our subjects is not known, core cooling can hardly be expected. A peripheral or skin cooling during the adaptation period as Rintamaki [13] described is more likely.

Body composition was not related to the metabolic or temperature response. However, there are also small changes in core temperature (Tintestine). The percentage body fat was related to this change in intestinal temperature. In extreme cold stress situations, like water immersion, FM is known to be important in preventing core cooling, when the cutaneous blood flow is minimal [36]. Our results suggest that even in mild cold, the fatness of a subject might play a role in insulation.

In several other studies describing moderate or mild-cold conditions, shivering occurred [37]. Our test conditions (air temperature and clothing) were carefully chosen in pilot studies, so that during cold exposure, no shivering would take place. Indeed, in the present study, increases in MR without shivering as registered by EMG was measured and noted by subjects and observer. Whether humans use NST is still under debate $[10,38]$. In the past, it has been shown that daily cold exposure results in an increase in metabolism with a gradual decrease of shivering, which indicates the existence of NST [39]. Several more recent studies point towards a significant contribution of NST in humans $[8,20,40,41]$. Although shivering cannot be completely ruled out from our measurements, these results make a significant contribution of ST unlikely. We recently found under more severe cold exposure, using the same experimental setup, that when shivering is evident, MR increases $30-60 \%$ as soon as shivering starts (Van Ooijen, in preparation). Our study thus indicates that NST seems to be a serious candidate for the observed increase in MR.

In the present experiment, no change in either SMR, $\mathrm{RMR}$, or $\mathrm{VO}_{2 \max }$ was found between seasons, independent of correction for the change in body composition. This means that a change in cold response due to a change in physical fitness can be excluded. Other studies report an effect on the metabolic response to severe cold explained by seasonal changes in RMR and maximum oxygen uptake. In these studies, however, the response is affected by higher levels of ST $[4,7,42]$.

As a heat-loss restricting mechanism, all skin temperatures decreased significantly in response to the mild cold. The decrease in skin temperatures was not significantly different between seasons. Because test conditions were identical in summer and winter and assuming that the subjects were in heat balance during the thermoneutral condition, the higher metabolic response to cold in winter indicates that, on average, the subjects showed less heat debt in winter. This has been described as an indicator for cold adaptation $[4,5]$. 
In summary, individual variation in cold response is observed, as shown by the inverse relation between the insulative and metabolic cold response. The significant relation of the metabolic response in winter versus the metabolic response in summer indicates that the type of cold response is subject specific. Although the pattern of the response seems to remain during acclimatization, the average magnitude of the metabolic response was increased in winter. There was no seasonal change in the insulative vasomotor response. Body heat debt thus was less during cold exposure in winter compared to summer. This means that even in a modern society (clothing and housing with central heating) in a moderate climate, cold acclimatization occurred.

\section{Acknowledgements}

We thank Martine Mol for data collection and enthusiastic support.

We thank Harry van Lenthe (University of Technology, Eindhoven, The Netherlands) for constructive comments. Furthermore, we thank the Department of Movement Sciences of Maastricht University for the availability of EMG equipment and Loek Wouters and Paul Schoffelen for technical support.

The experiments described in this paper comply with the current laws of The Netherlands.

\section{References}

[1] Dauncey MJ. Activity and energy expenditure. Can J Physiol Pharmacol 1990;68(1):17-27.

[2] van Marken Lichtenbelt WD, Schrauwen P, van De Kerckhove S, Westerterp-Plantenga MS. Individual variation in body temperature and energy expenditure in response to mild cold. Am J Physiol Endocrinol Metab 2002;282(5):E1077-83.

[3] van Ooijen AMJ, van Marken Lichtenbelt WD, Westerterp KR. Individual differences in body temperature and the relation to energy expenditure: the influence of mild cold. J Therm Biol 2001;26:455-9.

[4] Bittel JH. Heat debt as an index for cold adaptation in men. J Appl Physiol 1987;62(4):1627-34.

[5] Bittel J. The different types of general cold adaptation in man. Int J Sports Med 1992;13(Suppl. 1):S172-6.

[6] Bell DG, Tikuisis P, Jacobs I. Relative intensity of muscular contraction during shivering. J Appl Physiol 1992;72(6):2336-42.

[7] Eyolfson DA, Tikuisis P, Xu X, Weseen G, Giesbrecht GG. Measurement and prediction of peak shivering intensity in humans. Eur J Appl Physiol 2001;84(1-2):100-6.

[8] Vybiral S, Lesna I, Jansky L, Zeman V. Thermoregulation in winter swimmers and physiological significance of human catecholamine thermogenesis. Exp Physiol 2000;85(3):321-6.

[9] Lesná I, Vybíral S, Jansky L, Zeman V. Human nonshivering thermogenesis. J Therm Biol 1999;24:63-9.

[10] Jansky P, Jansky L. Sites and cellular mechanisms of human adrenergic thermogenesis: a review. J Therm Biol 2002;27:269-77.

[11] Levine JA, Eberhardt NL, Jensen MD. Role of nonexercise activity thermogenesis in resistance to fat gain in humans [see comments]. Science 1999;283(5399):212-4.
[12] Bittel JH, Nonotte-Varly C, Livecchi-Gonnot GH, Savourey GL, Hanniquet AM. Physical fitness and thermoregulatory reactions in a cold environment in men. J Appl Physiol 1988;65(5):1984-9.

[13] Rintamaki H. Human cold acclimatisation and acclimation. Int $\mathrm{J}$ Circumpolar Health 2001;60(3):422-9.

[14] Huttunen P, Lando NG, Meshtsheryakov VA, Lyutov VA. Effects of long-distance swimming in cold water on temperature, blood pressure and stress hormones in winter swimmers. J Therm Biol 2000;25:171-4.

[15] O'Brien C, Young AJ, Lee DT, Shitzer A, Sawka MN, Pandolf $\mathrm{KB}$. Role of core temperature as a stimulus for cold acclimation during repeated immersion in 20 degrees $\mathrm{C}$ water. J Appl Physiol 2000;89(1):242-50.

[16] Young AJ, Muza SR, Sawka MN, Gonzalez RR, Pandolf KB. Human thermoregulatory responses to cold air are altered by repeated cold water immersion. J Appl Physiol 1986;60(5):1542-8.

[17] Blaza S, Garrow JS. Thermogenic response to temperature, exercise and food stimuli in lean and obese women, studied by $24 \mathrm{~h}$ direct calorimetry. Br J Nutr 1983;49(2):171-80.

[18] Dauncey MJ. Influence of mild cold on $24 \mathrm{~h}$ energy expenditure, resting metabolism and diet-induced thermogenesis. Br J Nutr 1981; 45(2):257-67.

[19] Nagashima K, Yoda T, Yagishita T, Taniguchi A, Hosono T, Kanosue $\mathrm{K}$. Thermal regulation and comfort during a mild-cold exposure in young Japanese women complaining of unusual coldness. J Appl Physiol 2002;92(3):1029-35.

[20] Warwick PM, Busby R. Influence of mild cold on $24 \mathrm{~h}$ energy expenditure in 'normally' clothed adults. Br J Nutr 1990;63(3):481-8.

[21] Leonard WR, Sorensen MV, Galloway VA, Spencer GJ, Mosher MJ, Osipova L, et al. Climatic influences on basal metabolic rates among circumpolar populations. Am J Human Biol 2002;14(5):609-20.

[22] Scholander PF, Hammel HT, Hart JS, LeMessurier DH, Steen J. Cold adaptation in Australian aborigines. J Appl Physiol 1958;13:211-8.

[23] Bittel J. Cold adaptation-its relevance for long term exposure. In: Book Holmer I, Kuklane K, editors. Cold adaptation - its relevance for long term exposure. Solna: Arbete Och Hälsa; 1998. p. 147-51.

[24] Ravussin E, Lillioja S, Knowler WC, Christin L, Freymond D, Abbott WG, et al. Reduced rate of energy expenditure as a risk factor for body-weight gain. N Engl J Med 1988;318(8):467-72.

[25] Rising R, Keys A, Ravussin E, Bogardus C. Concomitant interindividual variation in body temperature and metabolic rate. Am J Physiol 1992;263(4 Pt 1):E730-4.

[26] Siri WE. Body composition from fluid spaces and density: analysis of methods. In: Book Brozek J, Henschel A, editors. Body composition from fluid spaces and density: analysis of methods. Washington (DC): National Academy of Sciences; 1961. p. 223-44.

[27] Ellis KJ. Human body composition: in vivo methods. Physiol Rev 2000;80(2):649-80.

[28] Westerterp KR, Wouters L, van Marken Lichtenbelt WD. The Maastricht protocol for the measurement of body composition and energy expenditure with labeled water. Obes Res 1995;3(Suppl. 1):49-57.

[29] Schoffelen PF, Westerterp KR, Saris WH, Ten Hoor F. A dual-respiration chamber system with automated calibration. J Appl Physiol 1997;83(6):2064-72.

[30] Weir JB. New methods for calculating metabolic rate with special reference to protein metabolism. 1949 [classical article]. Nutrition 1990;6(3):213-21.

[31] Webb P. The physiology of heat regulation. Am J Physiol 1995;268 (4 Pt 2):R838-50.

[32] O'Brien C, Hoyt RW, Buller MJ, Castellani JW, Young AJ. Telemetry pill measurement of core temperature in humans during active heating and cooling. Med Sci Sports Exerc 1998;30(3):468-72.

[33] Tikuisis P, Bell DG, Jacobs I. Shivering onset, metabolic response, and convective heat transfer during cold air exposure. J Appl Physiol 1991;70(5):1996-2002.

[34] Ramanathan NL. A new weighting system for mean surface temperature of the human body. J Appl Physiol 1964;19(3):531-3. 
[35] Contaldo F, Scalfi L, Coltordi A, Lanzilli A. Reduced cold-induced thermogenesis in familial human obesity. Klin Wochenschr 1986;64: $177-80$.

[36] Dulac S, Quirion A, DeCarufel D, LeBlanc J, Jobin M, Cote J, et al. Metabolic and hormonal responses to long-distance swimming in cold water. Int J Sports Med 1987;8(5):352-6.

[37] Inoue Y, Nakao M, Ueda H, Araki T. Seasonal variation in physiological responses to mild cold air in young and older men. Int $\mathrm{J}$ Biometeorol 1995;38(3):131-6.

[38] Nedergaard J, Golozoubova V, Matthias A, Asadi A, Jacobsson A, Cannon B. Ucp1: the only protein able to mediate adaptive nonshivering thermogenesis and metabolic inefficiency. Biochim Biophys Acta 2001;1504(1):82-106.
[39] Davies TRA. Chamber cold acclimatization in man. J Appl Physiol 1961;16:1011-5.

[40] Paolone VJ, Paolone AM. Thermogenesis during rest and exercise in cold air. Can J Physiol Pharmacol 1995;73(8):1149-53.

[41] Westerterp-Plantenga MS, Marken Lichtenbelt WD, Schrauwen P. Core-skin gradient of body temperature related to non-shivering thermogenesis 3 in humans at a lowered ambient temperature. J Therm Biol 2001;26:467-72.

[42] Ingemann-Hansen T, Halkjaer-Kristensen J. Seasonal variation of maximal oxygen consumption rate in humans. Eur J Appl Physiol Occup Physiol 1982;49(2):151-7. 